両側卵巣転移をきたした神経内分泌細胞を伴う直腸腺癌の 1 切除例

$$
\begin{aligned}
& \text { 太田西ノ内病院外科 } \\
& \text { 猪狩公宏松山貴俊飯田道夫 } \\
& \text { 熊谷洋一山崎繁 }
\end{aligned}
$$

大腸蹈の卵巣転移は比較的稀な転移形式である. 症例は75歳, 女性. 下腹部痛, 便秘 を主訴に, 直腸癌両側卵巣転移の診断にて Hartmann 手術を施行した. 両側卵巣転移お よび大網, 腹膜播種より P3 Stage IV と診断した。 また大晹癌卵巣転移の多くは中高分 化型腺癌の組織型を示すのに対し, 本症例ては synaptophysin, NSE, chromogranin に 陽性を示す神経内分泌腫㾺の成分を伴っておう, moderately differentiated adenocarcinoma with neuroendocrine differentiation と診断した. 大腸癌卵巣転移は発見時に 腹膜播種をきたしている例が多く, neuroendocrine cell carcinoma は adenocarcinoma に比し予後は不良であり, 本症例は転移様式および組織型から考えて, 極めて悪性度が 高い.

索引用語：大腸癌, 卵巣転移, neuroendocrine cell carcinoma

はじめに

転移性卵巣腫癔は胃笛が原発であることが多く, 大 腸癌からの転移は稀である.また原発巣の組織型で多 いのは中高分化腺癌である.今回われわれは, neuroendocrine differentiation を伴う中分化腺瘦である直腸 㿋原発の転移性卵巣腫赤の 1 例を経験したので若干の 文献的考察を加え報告する.

$$
\text { 症例 }
$$

患者：75歳, 女性.

主訴：下腹部痛, 便秘.

既往歴：子宮筋腫（筋腫核出術施行）.

家族歴：特記事項なし。

現病歴：2006年 4 月下旬頃より下腹部痛, 便秘が出 現し 5 月11日に近医を受診した。しかし症状は軽块せ ず, 5 月16日当院消化器科を受診した. 徐々に腹部膨 满感も出現し，大腸内視鏡検查にて肛門縁より $15 \mathrm{~cm}$ の箇所に 2 型狭窄性病変を認めたため, 治療もかねて 経肛門的イレウス管を捜入した。しかし症状は轾快せ ず 5 月22日，緊急手術施行目的に当科転科となった。

入院時身体所見 : 腹部では下腹部を中心に圧痛, 腹

2006年 8 月15日受付 2006年 9 月11日採用 〈所属施設住所〉

テ963-8558 郡山市西/内 $2-5-20$
部膨隆を認めた。腸雑音は軽度亢進していた。

検查所見 : WBC $: 14,600 / \mu \mathrm{l}, \mathrm{CRP}: 3.82 \mathrm{mg} / \mathrm{dl}$ と 炎症反応の高值とCEA : $113.5 \mathrm{ng} / \mathrm{ml}, \mathrm{CA19}-9$ ： $2148.0 \mathrm{U} / \mathrm{ml}$ と腫癌マーカーの上昇を認めた.

腹部単純エックス線検査 : niveau 像を伴う小腸, 大腸ガス像を認めた。

腹部単純 CT 検查（図 1)：Rs〜Ra 領域にかけて の壁肥厚像を認めた. 骨盤腔には左が $10 \times 8 \mathrm{~cm}$, 右が $8 \times 6 \mathrm{~cm}$ の low density な腫瘤を認めた。

以上より直腸癌, 両側卵巣転移の診断にて 5 月 22 日 に手術を施行した.

手術所見：中下腹部正中切開にて開腹. 腹水は中等 量貯留していた。骨盤腔内には右が $8 \mathrm{~cm}$, 左が $10 \mathrm{~cm}$ と 腫大した卵巣を認め摘出した. 結腸間膜, 後腹膜, 大 網には白色の腹膜播種巣があり, 大網の播種巣は切除 した。原発巣は $\mathrm{S}$ 状結腸から直腸までを切除し, 下行 結腸を人工肛門とする Hartmann 手術を施行し, 手術 を終了した。

切除標本：原発巣は半周性の 2 型病変て $40 \times 30 \mathrm{~mm}$ (図 2 a ). 卵巣は右が $80 \times 70 \times 45 \mathrm{~mm}$, 左が $100 \times 85 \times$ $80 \mathrm{~mm}$ と腫大しており，充実性の内容であった（図 2 b ). 組織型は adenocarcinoma だが, synaptophysin, NSE, chromogranin に陽性を示す endocrine carcinomaの成分も認めた．同様の所見を卵巣および大 


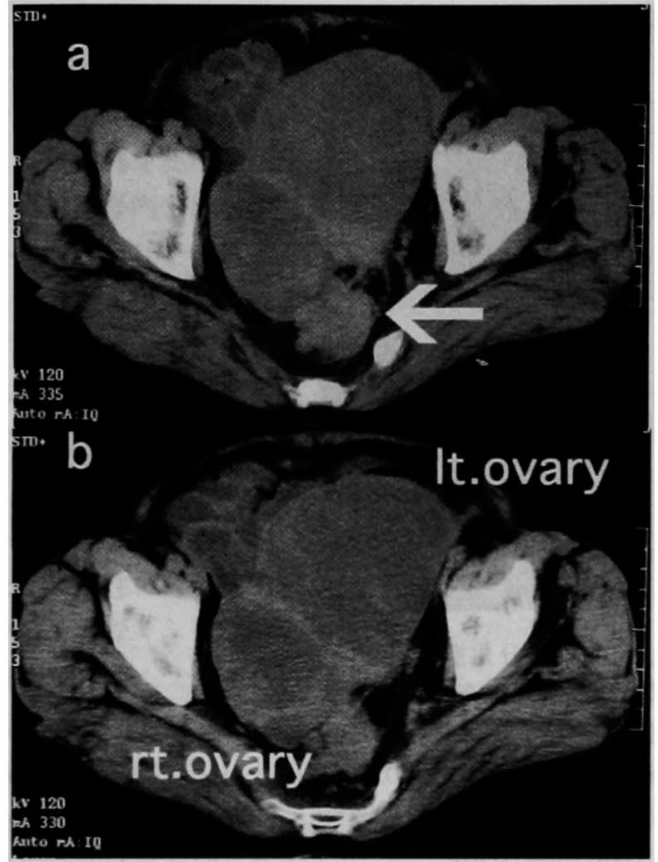

図 1 腹部単純 CT：a）矢印の部位に直腸壁の肥厚 像を認めた。 b)左卵宩は $10 \times 8 \mathrm{~cm}$ ，右卵巣は $8 \times$ $6 \mathrm{~cm} の$ low density な腫㾇として認めた。

網にも認めた（图 3 a 〜 d). 提出した No.241のリン パ節には転移を認めなかった。術後診断は, moderately differentiated adenocarcinoma with neuroendocrine differentiation, Ra、2 型, $40 \times 30 \mathrm{~mm}, \mathrm{SE}, \mathrm{N} 0, \mathrm{H} 0$, P3(両側卵单, 大網, 腹膜), M0, Stage IVであった.

術後経過：術後創感染を認めたが保存的治療により 軽块し，第40病日， 7 月 1 日に退院となった。腹膜播 種もあり術後化学療法を考虑したが本人が加療を希望 せず，現在外来で経過観察中である。

\section{考察}

転移性卵单腫場は，1896年, Friedrich Krukenberg が fibrosarcoma ovarii mucocellulare carcinomatodesという組織像をもつ卵巣腫瘍を Krukenberg 腫瘍と提唱したのが最初である. 1902年, Schlagenhaufe は, Krukenberg 腫瘍を消化器系より の二次性転移を示す卵巣腫瘍であると報告した。現在 では胃のみならず，その他の腹腔内外臟器の原発巣か ら卵巣に転移した腫痬が Krukenberg 腫場と呼ばれ ている1). 主な原発巣として本邦では胃癌が最多の $87.9 \%$ であり ${ }^{2)}$, 大腸㾮は稀とされている。一方欧米で 大腸癌, 乳癌原発によるものが多く, 人種差による葴

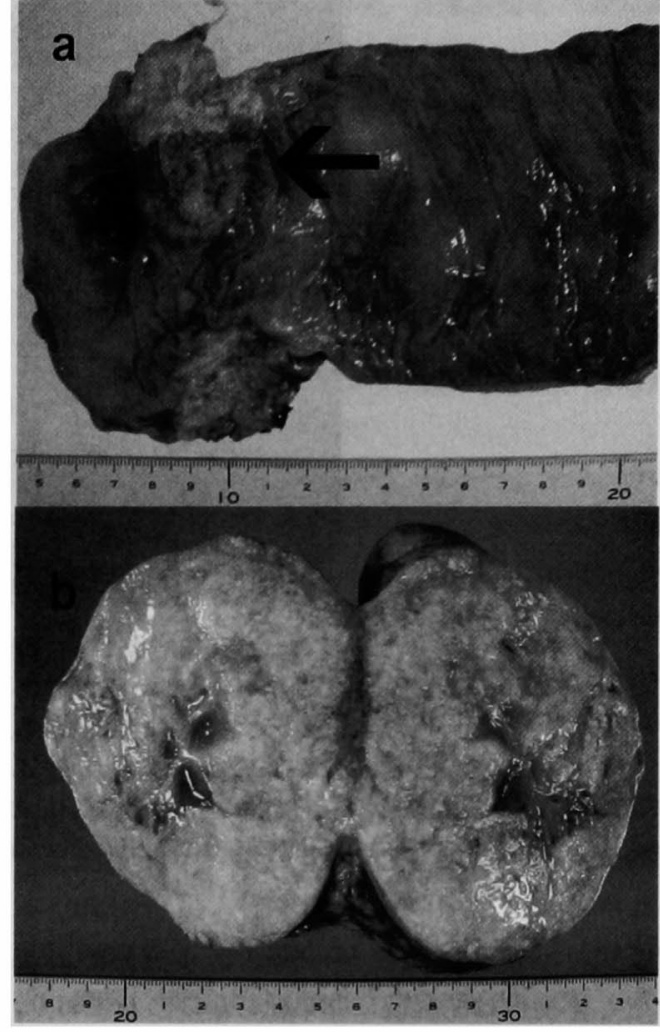

図 2 切除標本：a：直腸) Ra 領域に $40 \times 30 \mathrm{~mm}$ の 半周性の 2 型病変を認め (矢印), 腫瘍は獎膜面まて 露出していた。 b : 左卵巣割面) 多房性の充実性腫 留であった。

器の癌発生頻度との関連が示唆されている. 卵巣転移 率においても本邦では胃癌で最も多く28.9〜 42.3\%で

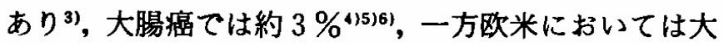
腸癌で約 $6 \%$ の転移率を示し，本邦を上回っている7. また直腸癌に限ると卵巣転移の発生率は $1 \%$ ()であ り, 結腸癌での発生より稀である。

大腸癌による転移性卵巣腫瘍の好発年齢は卵巣機能 が活発な30〜 40歳成閉経前に多い. 理由として血管が 豊富であること，排卵による卵膜被膜の損傷やホルモ ン的因子が転移に有利であると考えられている ${ }^{8)}$. 卵 宩転移の経路としては, 腹膜播種性, 血行性, リンパ 行性などが考えられる。腹膜播種性転移に関しては, 卵巣転移例の $38.4 \%$ に腹膜播種がみられており，播種 巣からの浸潤は考えなければならない9．血行性転移 については, 大腸と卵巣との間にリンパの交通がない ことや, リンパの逆流が稀であることなどから支持さ れており710)，リンパ行性転移については，転移例にお 


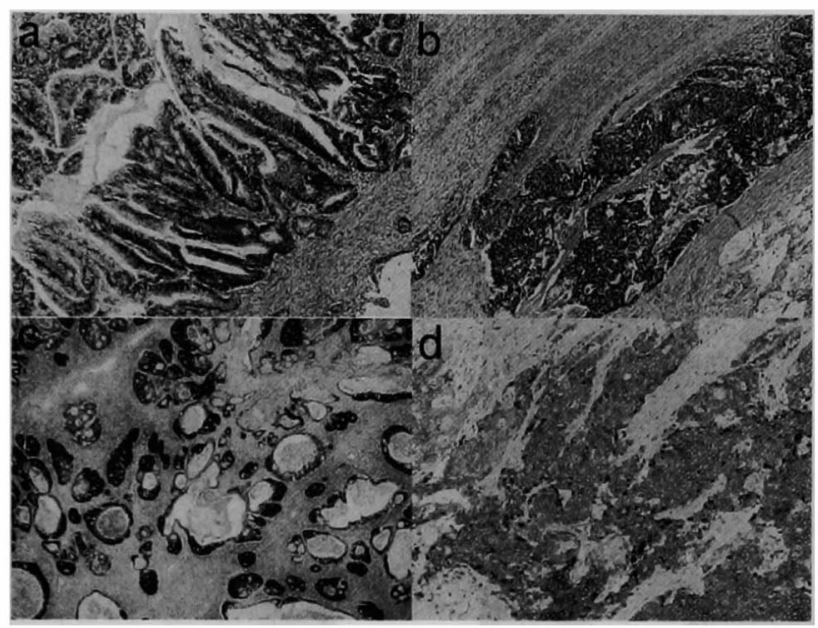

図3 病理組織像：a：直腸 HE 染色 $\times 100 ）$ 中分化腺瘦を認め る、b：直腸 $\mathrm{HE}$ 染色 $\times 100 ）$ 腺管構造を認めず, 充実性の增殖 を示す異型細胞を認める. c : 左卵巣 $\mathrm{HE}$ 染色 $\times 40$ ) 直腸と同様 に腺瘤構造を認めた。 d : 直腸 synaptophysin 染色 $\times 200)$ b の 部位は synaptophysin に陽性を示す神経内分泌細胞成分であっ た. 同様に NSE, chromogranin にも陽性を示した。

けるリンパ管侵襲陽性率の高さから支持されてい $3^{4556)}$. 本症例は閉経後に卵巣転移がみられており,リ ンパ管侵襲はあるものの, 腹膜播種が高度でもあるこ とから，播種性経路が最も考えられる。

卵巣転移巣の腫瘤は小さな時は充実性であるが，増 大するにつれて混合性, 多房性囊胞性病変としてみら れる. 組織学的には卵巣原発の粘液性腺癌や類内膜癌 と誤診されやすいが, 卵巣原発の場合は良悪性の移行 像や混在がみられ，転移例では悪性像のみである点で 鑑別となる。転移は両側例が多いとされており欧米で は43\% ${ }^{11)}$ ，本邦では $38.4 \%$ との報告がある ${ }^{9}$. 原発巣の 病理組織学的所見は, 中, 高分化腺癌で深達度 SS以

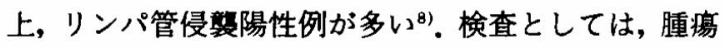
マーカーの測定および各種画像診断法があげられる. 腫場マーカーとしてはCEA が最も有用であり，CEA 上昇が自覚症状に先行することもある(2).さらに転移 性卵巣腫愓では CEA のみならずCA125やCA19-9の 併用も有用とされている. 画像診断法としては超音波 検査, CT, MRI などが有用である. 超音波検査では充 実性, 暴胞性病変の混在した像が描出されこれは CT でもMRIでも同様だが, 特に MRIでは内部の粘液や 奬液, 壊死, 新旧の出血などを反映して多彩な信号パ ターンを呈する。また原発巣が小さくとも転移巣は平 均 $11 \mathrm{~cm}$ と大きいことが多い(3). 本症例でも原発巣は
$40 \times 30 \mathrm{~mm}$ と大きくはないが, 卵巣転移は右が $8 \mathrm{~cm}$, 左が $10 \mathrm{~cm}$ と巨大な腫瘤を形成していた。

卵巣転移の多くは, 大腸癌原発巣が卵巣に浸潤また は近接するか肉眼的に烡胞などの異常を認める同時性 転移で, 異時性転移の報告は少ない. 同時性では 5 年 生存の報告が散見されるが, 異時性は約半数に腹膜播 種を合併し 5 年生存率は $0 \%{ }^{14)}$ で, 予後不良である.長 期生存例の特徵は, 高分化腺癌である, 転移が卵巣の みで遠隔縅器転移がない, 卵巣転移が比較的早期の段 階で切除されだなどであり，大腸癌切除時の予防的 卵巣摘出についての議論がなされている.45歳以上の 症例では手術時すでに $10 \%$ 症例に卵巣転移があるこ とを根拠に, 閉経後の患者は全例両側卵巣摘出の適応 としている報告もある(10).一方, 大腸癌切除時の卵巣摘 出は 5 年生存率を含め予後に影響しないことから卵巣 摘出の意義はないとしているものもある7). 本邦では,明 らかに卵巣に晎胞などの形態異常を伴う症例, 閉経後て 洯膜に明らかな浸潤を生じリンパ節転移を伴う症例を 予防的卵巣摘出術の適応としているところが多い ${ }^{121}$.

また本症例の組織型は中分化型の腺癌と内分泌紐胞 の混在が特徴的である. 神経内分泌腫㷎 (neuroendocrine cell carcinoma）は, 消化管, 膵, 肺, 甲状腺, 副甲状腺, 皮有などの神経内分泌細胞より発生し, 消 化管では虫垂や回腸に多く，大腸の中ては盲腸と直腸 
に多いとされている ${ }^{15)}$. 大腸癌全体の中での発生頻度

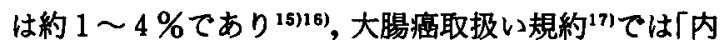
分泌細胞癌」に分類されるが，過去に低分化癌とされ ていた症例を免疫組織学的に再検討したところ，50\% 近くが神経内分泌腫瘀であったとする報告もあり ${ }^{16)}$, 一般にいわれているよりも発生頻度はやや高いと考え られる. 本症例のように内分泌細胞癌に腺癌が混在し ている症例は, 1983年から医学中央雑誌刊行会で調へ 得た限りては 7 例と極めて稀である. 予後は一般的に 不良で,診断時すでに広籍囲に転移があることが多く， 5 年生存率は $0 \sim 6 \%$ とされる ${ }^{18)}$. 免疫組穖学的なマ 一カーとしては, synaptophysin, NSE, chromogranin などが陽性になることが多い。治療法として確立され たものはなく，神経内分泌腫瘍を小細胞癌と考え肺小 細胞癌に準じた治療法を行い奏効した報告例199はあ る.また2005年 4 月より本邦でも使用可能となった oxaliplatin を含むFOLFOX regimen p FOLFIRI regimenはこれまでの化学療法と比し, 無再発期間・ 生存期間延長を認めており ${ }^{20)}$, 神経内分泌腫瘍でも，そ の有効性が期待できる可能性もある。しかし，本症例 は組織学的に考えて,さらに腹膜播種を伴う両側卵巣 転移も認めており, 術後化学療法を行っていないこと を考えると予後は厳しいことが予想される。

\section{結 語}

今回, われわれは直腸癌卵巣転移という稀な転移形 式であり，さらに neuroendocrine differentiation を 伴う中分化腺癌という稀な組織型でもある1例を経験 したので文献的考察とともに報告した。

\section{文 嗝}

1) 中野一郎，船木芳則，生垣 茂他：卵巣転移大晹 副切除後 6 年生存の 1 例. 臨外 $48: 821-824$, 1993

2）杼口一成, 加藤 倿, 小川重男他：Krukenberg 氏 運痘一其の臨床と病理。日産婦会誌 $14: 219$ 223, 1962

3）森脇昭介, 高嶋成光, 北島武志他：転移性卵巣㯵

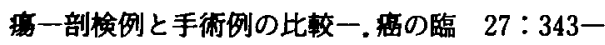
347,1981

4）藤吉 学, 磯本浩晴, 白木和雄他：大腸密の卵巣 転移に関する検討.日消外会誌 $22: 1116-1120$, 1989

5）山口俊昌，裹川公章，中本光春他：卵巣転移大腸 演の 4 例。日消外会誌 $22: 2882-2885,1989$

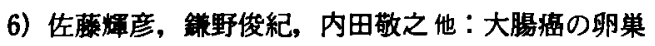

転移に関する臨床的研究。日本大腸肛門病会誌 $43: 56-60,1990$

7) Birnkrant A, Sampson J, Sugarbaker PH : Ovarian metastasis from colorectal cancer. Dis Colon Rectum 29 : 767-771, 1986

8）山口峰生, 小林 中：結腸癌治痹切除後卵巣転移 の 1 切除例. 臨外 $56: 949-952,2001$

9）富木裕一，鎌野伿紀，國井康弘他：多変量解析を 用いた大腸癌の卵巣転移危険因子の検討. 日消外 会誌 $35: 11-17,2002$

10) Graffner HOL, Alm POA, Oscarson JEA : Prophylactic oophorectomy in colorectal carcinoma. Am J Surg 146:233-235, 1983

11) Lash RH, Hart WR: Intestinal adenocarcinomas metastatic to the ovaries. A clinicopathologic evaluation of 22 cases. Am J Surg Pathol 11:114-121, 1987

12）田中 実, 中野昌志, 奥 雅志他: 直腸癌治瘾切 除後両側卵巣転移で再発した 1 例. 日本大腸肛門 病会誌 $45 ： 475-479,1992$

13）松崎健司, 竹内麻由美, 西谷 弘他：卵巣転移性 腫瘍. 産婦の実際 54：1559-1566，2005

14) Morrow M, Enker WE : Late ovarian metastases in carcinoma of the colon and rectum. Arch Surg 119: 1385-1388, 1984

15) Staren ED, Gould VE, Warren WH, et al: Neuroendocrine carcinoma of the colon and rectum : A clinicopathologic evaluation. Surgery $104: 1080-1089,1988$

16) Saclarides TJ, Szeluga D, Staren ED : Neuroendocrine cancers of the colon and rectum; Results of a ten-year experience. Dis Colon Rectum 37 : 635-642, 1994

17）大腸癌研究会編. 大腸癌取扱い規約. 改訂第 7 版, 金原出版, 東京, 2006

18）壁島康郎，高橋麻衣子，竜山哲章他：後頸部軟部 組織に初発転移をきたした neuroendocrine 分化 を示した直腸低分化腺癌の 1 例. 日消外会誌 $37: 241-246,2004$

19）湯川寞夫，赤池 信，杉政征夫他：術後化学療法 が奏効し長期生存中の直腸原発小細胞癌の 1 例.

日消外会誌 $35 ： 1443-1472,2002$

20）石黒敦，設楽紘平，棟方正樹他：大腸癌化学療 法最近の進歩。䔄の化療 $32: 2017-2023,2005$ 


\title{
A CASE OF BILATERAL OVARIAN METASTASIS FROM RECTAL ADENOCARCINOMA WITH NEUROENDOCRINE DIFFERENTIATION
}

\author{
Kimihiro IGARI, Takatoshi MATSUYAMA, Michio IIDA, \\ Youichi KUMAGAI and Shigeru YAMAZAKI \\ Department of Surgery, Ohta Nishinouchi Hospital
}

Ovarian metastasis is a comparatively rare mode of metastasis for rectal carcinoma. The patient was a 75 -year-old woman complaining of lower abdominal pain and constipation. She was diagnosed as having bilateral ovarian metastasis from rectal carcinoma and underwent a Hartmann operation. Since she had bilateral ovarian metastasis and omental and peritoneal dissemination, P3 Stage IV was diagnosed. While most ovarian metastases from rectal carcinoma show a histological type of moderately or well differentiated adenocarcinoma, this tumor in this case had components of neuroemdocrine tumor which were positive for synaptophysin, NSE, and chromogranin. Moderately differentiated adenocarcinoma with neuroendocrine differenatiation was thus diagnosed. Ovarian metastasis of rectal carcinoma often develops peritoneal dissemination when it is detected, and neuroendocrine cell carcinoma has poor prognosis compared to adenocarcinoma. From these facts, it is considered that the patient might have a poorest prognosis in terms of its mode of metastasis and histological type. 